\title{
APLIKASI HORMON OODEV DAN TEPUNG KUNYIT PADA PEMATANGAN INDUK IKAN PERES, Osteochilus kappeni
}

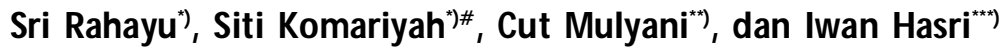 \\ *) Program Studi Akuakultur, Fakultas Pertanian, Universitas Samudra \\ Jl. Prof. Dr. Syarief Thayeb, Meurandeh, Langsa Lama, Langsa, Aceh 24416 \\ *) Program Studi Agroteknologi, Fakultas Pertanian, Universitas Samudra \\ **) Program Studi Budidaya Perairan, Fakultas Pertanian, Universitas Gajah Putih \\ Simpang Kelaping, Pegasing; Kota/KJabupaten, Aceh Tengah, Aceh 24552
}

(Naskah diterima: 19 Oktober 2021; Revisi final: 28 Desember 2021; Disetujui publikasi: 28 Desember 2021)

\begin{abstract}
ABSTRAK
Upaya untuk meningkatkan kematangan gonad induk ikan peres perlu adanya rangsangan baik melalui pakan maupun secara hormonal. Penelitian ini bertujuan untuk mengkaji pemberian hormon Oodev dan tepung kunyit pada pakan terhadap percepatan kematangan gonad ikan peres, Osteochilus kappeni. Metode yang digunakan adalah rancangan acak lengkap (RAL) dengan empat perlakuan dan tiga ulangan. Perlakuan dalam penelitian ini, yaitu P-1 (pakan komersil), P-2 (pakan komersil + 3\%tepung kunyit dan penyuntikan $0,5 \mathrm{~mL}$ Oodev), P-3 (pakan komersil + 3\%tepung kunyit dan penyuntikan $1 \mathrm{~mL}$ Oodev), P-4 (pakan komersil $+3 \%$ tepung kunyit). Induk ikan peres yang digunakan berjumlah 12 ekor, setiap perlakuan digunakan tiga induk ikan peres betina dengan bobot sekitar $118 \mathrm{~g}$. Parameter yang diamati yaitu pertambahan bobot mutlak (PBM), indeks kematangan gonad (IKG), fekunditas, tingkat kematangan gonad (TGK), dan diameter telur. Hasil penelitian menunjukkan bahwa pemberian tepung kunyit dalam pakan dan penyuntikan hormon Oodev berpengaruh nyata $(P<0,05)$ terhadap semua parameter pengamatan. Perlakuan terbaik terdapat pada perlakuan P2, yaitu menghasilkan PBM sebesar 20,9 g; IKG sebesar 18,35\% fekunditas sebanyak 2.560 butir, dan diameter telur $1,10 \mathrm{~mm}$. Penelitian ini menyimpulkan bahwa kombinasi $0,5 \mathrm{~mL}$ hormon Oodev dan 3\%tepung kunyit cukup untuk mempercepat kematangan gonad 0 . kappeni.
\end{abstract}

\section{KATA KUNCl: hormone; kunyit; gonad; diameter telur; fekunditas; Osteochilus}

ABSTRACT: Application of Oodevhormone and turmeric powder on maturation of Osteochilus kappeni broodfish. By: Sri Rahayu, Siti Komariyah, Cut Mulyani, and Iwan Hasri

Efforts to increase the gonad maturity of the peres broodfish require stimulation either through feed or hormonally. This study aimed to study the effects of feed supplemented with Oodev hormone and turmeric flour on accelerating gonadal maturity of Osteochilus kappeni. The experiment was arranged in a completely randomized design (CRD) consisting of four treatments and three replications. The treatment in this study were P-1 (commercial feed), P-2 (commercial feed $+3 \%$ turmeric powder and injection $0.5 \mathrm{ml}$ Oodev), P-3 (commercial feed $+3 \%$ turmeric flour and injection $1 \mathrm{~mL}$ Oodev), P-4 (commercial feed $+3 \%$ turmeric powder). Twelve adult fish were used in this study which each treatment was used three female fish weighted around $118 \mathrm{~g}$. The parameters observed were absolute weight gain, gonad maturity index, fecundity, gonad maturity level, and egg diameter. The results showed that the administration of Oodev hormone and turmeric powder in feed had a significant effect on the measured parameters. The absolute weight showed the highest results in P2 treatment of $20.7 \mathrm{~g}$. P2 treatment also had the highest gonad maturity index of $18.35 \%$ best fecundity of up to $2,560 \mathrm{eggs}$; and the largest egg diameter of $1.10 \mathrm{~mm}$. This study concludes that the combination of Oodev hormones and tumeric flour is sufficient to accelerate gonadal maturity of $\mathbf{0}$. kappeni.

KEYWORDS: hormone; turmeric; gonad; egg diameter; fecundity; Osteochilus

\# Korespondensi: Program Studi Akuakultur, Fakultas Pertanian,

Universitas Samudra. Jl. Prof. Dr. Syarief Thayeb, Meurandeh,

Langsa Lama, Langsa, Aceh 24416, Indonesia

E-mail: sitikomariyah_adam@ yahoo.com 


\section{PENDAHULUAN}

Ikan peres, Osteochilus kappeni adalah spesies asli yang tersebar di Danau Laut Tawar dan beberapa sungai di Aceh Tengah (Muchlisin \& Azizah, 2009; Marini \& Fahmi, 2015). Ikan peres termasuk dalam famili cyprinidae yang berpotensi untuk dikembangkan terutama di Aceh Tengah karena termasuk salah satu ikan air tawar yang digemari oleh masyarakat sekitar. Pengembangan ikan peres saat ini telah dilakukan oleh Balai Benih Ikan (BBI) Lukup Badak, Aceh Tengah.

Keberhasilan pengembangan budidaya ikan peres sangat ditentukan oleh penyediaan benih yang memiliki kualitas dan kuantitas yang baik. Ketersediaan induk matang gonad yang tidak memadai, dapat menghambat ketersediaan benih ikan peres secara berkelanjutan. Upaya untuk meningkatkan kematangan gonad induk ikan peres perlu adanya rangsangan baik melalui pakan maupun secara hormonal. Perangsangan kematangan gonad induk ikan peres secara hormonal telah dilakukan oleh Darliansyah et al. (2017) dan Lijana (2021). Namun hasil yang diperoleh belum optimal, sehingga perlu adanya kombinasi perangsangan kematangan gonad induk ikan peres secara hormonal dan melalui pakan.

Perangsangan kematangan gonad melalui pakan dapat dilakukan dengan memberikan nutrien-nutrien yang dapat memicu kematangan gonad seperti curcumin yang terkandung dalam tepung kunyit. Curcumin bersifat fitoestrogen dan hepatoprotektor dari golongan senyawa flavonoid yang dapat berperan sebagai estrogen yang mampu menstimulasi hati untuk menyintesis vitelogenin (Ravindran, 2007; Saraswati, 2013).

Sementara salah satu hormon yang sudah banyak aplikasi untuk merangsang kematangan gonad ikan adalah Oodev (Farastuti et al., 2014; Dhewantara \& Rahmatia, 2017; Tomasoa et al., 2018). Hormon Oodev (Oosyte development) adalah kombinasi antara hormon pregnant mare serum gonadotropin (PMSG) dan antido pamin. PMSG memuat lebih banyak follicle stimulating hormone (FSH) dibandingkan dengan luteuinizing hormone (LH). FSH diperlukan untuk menginduksi proses vitelogenesis dan mempercepat waktu pematangan gonad. Antidopamin akan menghambat kerja dopamin sehingga dapat memicu proses vitelogenesis yang berlangsung dalam gonad dan hati, serta merangsang pituitari dan hipotalamus melepaskan GnRH dan meningkatkan respons pemijahan (Farastuti et al., 2014).

Dari uraian di atas, aplikasi hormon Oodev dan tepung kunyit dalam pakan diharapkan mampu meningkatkan kematangan gonad induk ikan peres.

\section{BAHAN DAN METODE}

\section{Waktu dan Tempat}

Penelitian ini dilakukan pada bulan Januari-Februari 2021 di Balai Benih Ikan (BBI) Lukup Badak, Kecamatan Pegasing Kabupaten Aceh Tengah.

\section{Bahan dan Alat}

Bahan yang digunakan selama penelitian berupa induk ikan peres, hormon Oodev, pakan komersil, dan tepung kunyit. Sedangkan alat yang digunakan yaitu kolam beton berukuran 1,5 m x $1 \mathrm{~m} \times 1 \mathrm{~m}$, ember, mangkok, timbangan digital, jarum suntik, DO meter, pH meter, kateter, mikroskop, dan jaring.

\section{Metode penelitian}

Penelitian ini menggunakan rancangan acak lengkap (RAL) dengan empat perlakuan dan tiga ulangan sehingga dihasilkan 12 unit percobaan, yaitu:

$\mathrm{P}_{1}=$ pakan komersil (kontrol)

$\mathrm{P}_{2}=$ pakan komersil $+3 \%$ tepung kunyit dan penyuntikan Oodev $0,5 \mathrm{~mL} / \mathrm{kg}$

$\mathrm{P}_{3}=$ pakan komersil $+3 \%$ tepung kunyit dan penyuntikan Oodev $1 \mathrm{~mL} / \mathrm{kg}$

$\mathrm{P}_{4}=$ pakan komersil $+3 \%$ tepung kunyit

\section{Persiapan wadah}

Sebelum digunakan, empat kolam beton dibersihkan dan dikeringkan, kemudian diisi air setinggi $0,6 \mathrm{~m}$.

\section{Seleksi induk}

Induk ikan peres yang digunakan berumur 8-12 bulan dengan bobot rata-rata $118,33 \pm 14,67 \mathrm{~g}$ sebanyak 12 ekor. Induk yang digunakan adalah induk yang belum matang gonad yang sebelumnya telah dipijahkan untuk mengosongkan gonad yang ada di perut ikan tersebut. Adapun ciri-ciri induk yang belum matang gonad adalah bagian perut sudah tidak lagi membesar.

\section{Persiapan pakan uji}

Penambahan tepung kunyit pada pakan dilakukan dengan cara coating dengan tepung kunyit. Agar tepung kunyit merekat pada pakan, digunakan bahan tambahan yaitu progol dengan dosis $5 \mathrm{~g} / \mathrm{kg}$ pakan. Progol dan tepung kunyit dilarutkan pada $125 \mathrm{~mL}$ akuades, kemudian disemprotkan secara merata pada pakan. Setelah penyemptotan, pakan dikeringanginkan.

\section{Penyuntikan hormon Oodev}

Induk ikan peres betina disuntik hormon Oodev sesuai dosis perlakuan secara intramuscular. Penyuntikan dilakukan satu kali di awal penelitian, 
kemudian pada hari ke-7 dikateter untuk melihat tingkat kematangan gonad ikan peres.

\section{Pemeliharaan induk}

Pemeliharaan induk dilakukan selama 21 hari. Selama pemeliharaan, induk diberi pakan komersil untuk perlakuan kontrol (P-1) dan pakan uji untuk perlakuan P-2, P-3, dan P-4. Pemberian pakan dilakukan secara satiasi dengan frekuensi dua kali sehari, yaitu pada pukul 08.00 dan 18.00 WIB. Pengelolaan kualitas air dilakukan dengan mengganti air setiap tiga hari sekali sebanyak $50 \%$ serta penyifonan feses dan sisa pakan setiap pagi hari sebelum pemberian pakan.

\section{Kateterisasi}

Sampel telur diambil dengan cara melakukan striping pada perut ikan atau kateterisasi dan dilakukan pada hari ke-7 setelah penyuntikan. Telur yang sudah dikateter dilihat warnanya untuk memastikan tingkat kematangan gonad ikan peres secara kasat mata. Menurut Effendie (2002), pada TKG-IV secara kasat mata telur berwarna kuning dan mudah dipisahkan.

\section{Parameter yang diamati}

Parameter yang diamati yaitu pertambahan bobot mutlak (PMB), tingkat kematangan gonad (TKG), indeks kematangan gonad (IKG), fekunditas, diameter telur, dan kualitas air (pH, DO, dan suhu). Pertumbuhan bobot mutlak dapat dihitung menggunakan rumus Effendie (2002):

$$
\mathrm{PBM}=\mathrm{Bt}-\mathrm{Bo}
$$

\section{di mana:}

$\mathrm{PBM}=$ pertumbuhan bobot mutlak $(\mathrm{g})$

$\mathrm{Bt}=$ bobot ikan padaakhir pemeliharaan $(\mathrm{g})$

Bo $=$ bobot ikan pada awal pemeliharaan $(\mathrm{g})$

Indeks kematangan gonad (IKG) dihitung menggunakan rumus Johnson (1971) yaitu:

$$
\text { IKG }(\%)=\frac{B g}{B t} \times 100
$$

di mana:

IKG = indeks kematangan gonad $(\%)$

$\mathrm{Bg}=$ bobot gonad $(\mathrm{g})$

$\mathrm{Bt}=$ bo bot tubuh ikan $(\mathrm{g})$

Penghitungan fekunditas ikan peres dilakukan dengan menggunakan metode gravimetri berdasarkan Effendie (2002). Dan dapat dihitung dengan rumus berikut:

di mana:

$$
F=\frac{G}{Q} \times N
$$

$F=$ fekunditas (butir)

$\mathrm{G}=$ bobot tubuh $(\mathrm{g})$

$\mathrm{Q}=$ bobot gonad $(\mathrm{g})$

$\mathrm{N}=$ jumlah telur pada gonad (butir)
Rumus yang digunakan untuk menghitung besar diameter telur induk ikan peres (Farastuti et al., 2014):

$$
\mathrm{DS}=\mathrm{Dt}-\mathrm{Do}
$$

di mana:

$\mathrm{DS}=$ diameter telur sebenarnya $(\mathrm{mm})$

$\mathrm{Dt}=$ diameter telur akhir $(\mathrm{mm})$

Do $=$ diameter telur awal $(\mathrm{mm})$

\section{Analisis Data}

Data yang diperoleh dari hasil penelitian dianalisis sidik ragam (ANOVA) untuk melihat pengaruh perlakuan yang diberikan. Jika perlakuan yang diberikan berpengaruh nyata $(P<0,05)$ maka dilanjut dengan $\mathrm{Uji}$ Duncan. Sementara data kualitas air dianalisis secara deskriptif.

\section{HASIL DAN BAHASAAN}

Tingkat Kematangan Gonad (TKG) dan Waktu Matang

Berdasarkan hasil pengamatan, penyuntikan hormon Oodev, dan penambahan tepung kunyit pada pakan untuk tingkat kematangan gonad induk ikan peres menunjukkan berpengaruh (Tabel 1 ).

Tabel 1. Tingkat kematangan gonad (TKG) induk ikan peres (Osteochillus kappeni)

Table 1. Gonadal maturity level (GML) of brood fish, Osteochillus kappeni

\begin{tabular}{ccc}
\hline $\begin{array}{c}\text { Perlakuan } \\
\text { Treatments }\end{array}$ & $\begin{array}{c}\text { Tingkat kematangan gonad } \\
\text { Gonadal maturity level }\end{array}$ & $\begin{array}{c}\text { Waktu (hari) } \\
\text { Time (day) }\end{array}$ \\
\hline P-1 & Belum matang & 21 \\
P-2 & Immature & 7 \\
P-3 & IV & 7 \\
P-4 & IV & 18 \\
\hline
\end{tabular}

Tabel 1 menunjukkan bahwa perangsangan maturasi secara hormonal dan meningkatkan nutrisi pakan terbukti dapat mempercepat kematangan gonad. Hal ini ditunjukkan dengan perlakuan kontrol yang belum matang gonad hingga pemeliharaan selama 21 hari (tiga minggu). Sementara perlakuan lainnya sudah mencapai TKG-IV pada hari ke-7 (P-2 dan P-3) dan hari ke-14 (P-4). Selain itu, penyuntikan hormon Oodev akan mematangkan gonad induk ikan peres lebih cepat daripada pemberian tepung kunyit saja. Sedangkan pemberian dosis hormon Oodev 0,5 dan $1 \mathrm{~mL}$ (P-2 dan P-3) tidak berbeda nyata. Secara umum hormon Oodev memiliki efek biologis sama seperti peran follicle stimulatting hormone (FSH) yang paling banyak daripada luteinizing hormone (LH). FSH bekerja di dalam gonad, sedangkan LH akan mempercepat kerja 
maturasi hingga ovulasi (Farastuti et al., 2014). Anti dopamin dalam Oodev dapat memperlambat kerja dopamin sehingga hipotalamus dapat mensekresi gonadotropin releasing hormone (GnRH) ke dalam kelenjar putuitari (Fadhillah, 2016).

Tepung kunyit yang ditambahkan pada pakan juga dapat mempercepat kematangan gonad induk ikan peres dibanding perlakuan kontrol. Hal ini sesuai pernyataan Ravindran et al. (2007) dan Saraswati (2013), bahwa kunyit mengandung fitoestrogen yang memiliki kemampuan bertindak seperti estrogen, yang mampu untuk menyintesis vitelogenin.

Penelitian yang serupa telah dilakukan oleh Farida et al. (2018) bahwa penambahan tepung kunyit 3\%dan Oodev $0,5 \mathrm{~mL}$ dalam pakan dapat mempercepat kematangan gonad ikan biawan (Helostoma teminckii) selama empat minggu. Dalam penelitian Hasan et al. (2018) penambahan Oodev 0,5 mL dan $1 \mathrm{~mL} / \mathrm{kg}$ pakan dan tepung kunyit dalam pakan dapat memicu perkembangan testis induk ikan biawan (Helostoma teminckii) hampir $100 \%$ induk matang dalam waktu pemeliharaan 6-8 minggu. Kemudian penelitian Faridz et al. (2019) pemberian Oodev 0,5 mL/kg induk dan tepung kunyit $0,75 \mathrm{~mL} / \mathrm{kg}$ pakan berpengaruh terhadap pematangan induk ikan semah (Tor douronensis).

\section{Pertambahan Bobot Mutlak (PBM) dan Performa Reproduksi}

Hasil uji ANOVA perlakuan penyuntikan hormon Oodev dan penambahan tepung kunyit dalam pakan berpengaruh nyata $(P<0,05)$ terhadap pertambahan bobot mutlak (PBM), indeks kematangan gonad (IKG), fekunditas, dan diameter telur induk ikan peres (Tabel 2).

Tabel 2. menunjukkan bahwa PBM, fekunditas, dan diameter telur induk ikan peres pada perlakuan penyuntikan hormon Oodev dan penambahan tepung kunyit pada pakan (P-2, P-3, dan P-4) berbeda nyata $(P<0,05)$ dengan perlakuan kontrol $(P 1)$, sedangkan dosis hormon Oodev dan tepung kunyit (P-2, P-3, dan P-4) tidak berbeda nyata. Sementara pada parameter IKG, hasil uji Duncan menunjukkan bahwa penyuntikan hormon Oodev dengan dosis berbeda dan penambahan tepung kunyit pada pakan (P2 dan P3) berbeda nyata dengan kontrol (P-1), akan tetapi tidak berbeda nyata terhadap perlakuan penambahan tepung kunyit saja (P-4). Begitu juga halnya P-1 dan P-4 tidak tidak berbeda nyata.

Perlakuan P-2 (penambahan tepung kunyit pada pakan dan penyuntikan hormon Oodev $0,5 \mathrm{~mL} / \mathrm{kg}$ induk) memberikan hasil terbaik dibanding perlakuan lainnya, sementara pada perlakuan kontrol belum matang gonad, hal ini ditandai dengan nilai IKG dan fekunditas hanya nol. Tingginya pertumbuhan bobot mutlak pada P-2, P-3, dan P-4 diduga berkaitan dengan bertambahnya bobot gonad, artinya pada perlakuan P-2, P-3, dan P-4 terjadi kematangan gonad. Hal ini ditunjukkan dengan IKG yang tinggi dibanding pelakuan kontrol (P1). Sementara pada perlakuan P-1 pertambahan bobot mutlak yang cukup rendah karena pada perlakuan tersebut tidak terjadi penambahan bobot gonad yang artinya induk pada perlakuan P1 tidak matang gonad.

Pertambahan bobot gonad induk ikan peres pada perlakuan P-2, P-3, dan P-4 disebabkan karena adanya bahan aktif yang terkandung pada hormon Oodev dan tepung kunyit. Hormon Oodev mengandung senyawa pregnant mare-serum gonadotropin (PMSG) dan antido pamin. Hormon ini berfungsi untuk merangsang terjadinya lonjakan kadar Gonadotropin Releasing Hormone $(\mathrm{GnRH})$ yang kemudian memengaruhi kelenjar pituitari untuk memproduksi gonadotropin (Sudrajat $\&$ Rasid, 2020). Selanjutnya menurut Bolamba et al. (1992), gonadotropin akan merangsang ovari untuk proses pematangan telur pada ikan. Selain hormon, kurkumin yang terkandung dalam tepung kunyit juga dapat meningkatkan pertambahan bobot dan perkembangan gonad induk ikan peres. Hal ini sesuai dengan Sari (2016) bahwa kandungan kurkumin pada kunyit bekerja sebagai pelindung hati, mengoptimalkan produksi dan fungsi vitalogenin untuk mendorong pertumbuhan kelenjar genital.

Menurut Sari et al. (2019), perkembangan gonad memengaruhi indeks kematangan gonad. Jika kematangan gonad meningkat, maka akan meningkat pula nilai IKG. Effendie (2002) dalam Dhewantara \& Rahmatia (2017) juga menyatakan bahwa nilai indeks kematangan gonad adalah kuantitatif yang terjadi pada gonad dan peningkatan nilai indeks pematangan gonad sejalan dengan perkembangan gonad yang matang.

Berdasarkan hasil penelitian yang telah dilakukan, hasil penelitian ini serupa dengan penelitian yang dilakukan oleh Purwati (2017) bahwa pertumbuhan gonad akan memengaruhi pertambahan bobot induk ikan sehingga akan memengaruhi nilai IKG. Hal ini diperkuat dengan pendapat Makmur et al. (2003) yang menyatakan bahwa bo bot tubuh dan bobot gonad ikan dapat berpengaruh terhadap nilai IKG. Nilai IKG pada penelitian ini jauh lebih rendah jika dibandingkan dengan IKG ikan peres yang diberi hormon PMSG + AD yaitu mencapai 32,78\% (Darliansyah et al., 2017), dan pemberian hormon Spawnprime dan Ovaspec IKG mencapai 20,29\%(Lijana, 2021).

Berdasarkan uji statistik, penyuntikan hormon dan penambahan tepung kunyit pada pakan perlakuan ( $\mathrm{P}-2$ dan P-3), serta penambahan tepung kunyit pada pakan (P-4) memberi pengaruh yang sama terhadap fekunditas ikan peres. Namun secara deskriptif, induk 
Tabel 2. Pertambahan bobot mutlak (PBM), indeks kematangan gonad (IKG), fekunditas dan diameter telur induk ikan peres (Osteochillus kappeni)

Table 2. Absolute weight gain (AWG), gonad maturity index (GMI), fecundity and egg diameter of broodfish, Osteochillus kappeni

\begin{tabular}{ccccc}
\hline $\begin{array}{c}\text { Perlakuan } \\
\text { Treatments }\end{array}$ & $\begin{array}{c}\text { Pertambahan } \\
\text { bobot mutlak } \\
\text { Absolute weight } \\
\text { gain (g) }\end{array}$ & $\begin{array}{c}\text { Indeks kematangan } \\
\text { gonad } \\
\text { Gonadal maturity } \\
\text { index (\%) }\end{array}$ & $\begin{array}{c}\text { Fekunditas } \\
\text { (butir) } \\
\text { Fecundiy } \\
\text { (egg) }\end{array}$ & $\begin{array}{c}\text { Diameter telur } \\
\text { Egg diameters } \\
\text { (mm) }\end{array}$ \\
\hline P-1 & $5.3 \pm 1.20^{\mathrm{a}}$ & $0.00 \pm 0.00^{\mathrm{a}}$ & $0.00 \pm 0.00^{\mathrm{a}}$ & $0.00 \pm 0.00^{\mathrm{a}}$ \\
P-2 & $20.7 \pm 4.06^{\mathrm{b}}$ & $18.35 \pm 5.15^{\mathrm{b}}$ & $2,560.41 \pm 319.25^{\mathrm{b}}$ & $1.10 \pm 0.01^{\mathrm{b}}$ \\
P-3 & $19.0 \pm 2.56^{\mathrm{b}}$ & $16.65 \pm 2.82^{\mathrm{b}}$ & $2,418.53 \pm 249.52^{\mathrm{b}}$ & $1.08 \pm 0.05^{\mathrm{b}}$ \\
P-4 & $16.3 \pm 2.73^{\mathrm{b}}$ & $14.27 \pm 3.08^{\mathrm{ab}}$ & $1,742.70 \pm 307.91^{\mathrm{b}}$ & $1.01 \pm 0.01^{\mathrm{b}}$ \\
\hline
\end{tabular}

Keterangan: Huruf yang berbeda pada kolom yang sama menunjukkan perlakuan berbeda nyata $(P<0,05)$

Note: Different letters in the same column indicate significantly different treatments $(P<0.005)$

yang disuntik hormon Oodev (P-2 dan P-3) memiliki fekunditas yang lebih tinggi dibanding dengan induk yang hanya diberi tepung kunyit. Hal ini menunjukkan bahwa penyuntikan hormon Oodev dapat meningkatkan nilai fekunditas induk ikan peres. Fekunditas tertinggi pada penelitian ini mencapai $2.560,41$ butir. Sedangkan dengan pemberian hormon yang berbeda yaitu Spawnprime dan Ovaspec pada ikan dengan umur yg sama, fekunditas induk ikan peres bisa mencapai 29.552,3 butir (Lijana, 2021). Besar kecilnya nilai fekunditas disebabkan oleh beberapa faktor seperti umur dan ukuran ikan. Hal ini sesuai dengan pernyataan Unus \& Umar (2010) bahwa banyaknya telur yang diovulasikan untuk jenis ikan yang sama dapat dipengaruhi oleh lingkungan, ukuran tubuh, dan umur ikan.

Pada perlakuan P-2, P-3, dan P-4; hormon Oodev dan tepung kunyit memberi efek pada ukuran telur di dalam gonad. Hal ini dikarenakan adanya kecukupan nutrisi yang terkandung dalam pakan yang dapat meningkatkan kinerja reproduksi dan tingkat kematangan gonad induk ikan peres. Hal ini sesuai menurut Effendie (2002), semakin matang gonad, semakin besar diameter pada ovarium. Besarnya diameter telur karena adanya penyerapan pada lumen ovarium oleh stimulasi hormon yang tepat.

Diameter telur tertinggi pada penelitian ini yaitu $1,10 \mathrm{~mm}$; hampir sama dengan penelitian sebelumnya dengan pemberian hormon PMSG + AD yaitu 1,09 $\mathrm{mm}$ (Darliansyah et al., 2017). Sementara pada penelitian Lijana (2021) dengan pemberian hormon Spawnprime dan Ovaspec pada ikan peres menghasilkan diameter telur hanya $0,36 \mathrm{~mm}$. Hasil penelitian ini dan Lijana (2021) sesuai dengan penyataan Wootton (1990) bahwa diameter telur berbanding terbalik dengan fekunditas. Ikan mempunyai fekunditas lebih banyak biasanya diameter telurnya lebih kecil, dan sebaliknya. Selain itu, Bulanin et al. (2016) juga menyatakan bahwa besar kecilnya diameter telur pada ikan dipengaruhi oleh bobot gonad ikan, semakin besar gonad ikan maka diameter telurnya kecil dan jumlah fekunditasnya banyak dan semakin kecil bo bot gonad maka semakin besar diameter telur ikan dan semakin rendah nilai fekunditasnya.

\section{Kualitas Air}

Kualitas air adalah faktor eksternal yang berpengaruh terhadap pertumbuhan dan reproduksi ikan peres. Parameter kualitas air pada wadah perlakuan yang digunakan selama penelitian masih dalam satu kisaran yang sama., DO berkisar antara 2,0-4,7 mg/L; pH antara 6 hingga 7,8; dan suhu berkisara pada $20^{\circ} \mathrm{C}$ hingga $23^{\circ} \mathrm{C}$.

\section{KESIMPULAN}

Aplikasi hormon Oodev dan tepung kunyit pada pakan berpengaruh nyata $(P<0,05)$ meningkatkan pertambahan bobot mutlak, mempercepat tingkat kematangan gonad dan IKG induk ikan peres. Perlakuan terbaik aplikasi hormon Oodev dan tepung kunyit pada penelitian ini yaitu perlakuan P-2 (penyuntikan hormon Oodev $0,5 \mathrm{~mL}$ dan penambahan $3 \%$ tepung kunyit pada pakan komersil) dapat meningkatkan persentase terhadap semua parameter. Sebagai bahan pertimbangan dengan penggunaan dosis hormon Oodev disarankan cukup menggunakan hormon Oodev berdosis rendah saja. Tepung kunyit dapat disarankan sebagai alternatif untuk pematangan gonad induk ikan peres karena lebih ekonomis.

\section{UCAPAN TERIMA KASIH}

Penulis mengucapkan terima kasih kepada kepala UPTD Balai Benih Ikan (BBI) Lukup Badak, Aceh Tengah yang telah memberikan izin untuk melaksanakan penelitian. 


\section{DAFTAR ACUAN}

Bolamba, D., Matton, P., Estrada, R., \& Dufour, J.J. (1992). Effects of Pregnant Mare's Serum Gonadotropin Treatment on Follicular Populations and Ovulation Rates in Prepuberal Gilts with Two Morphologically Different Ovarian Types. Journal of Animal Science. 70(6), 1916-1922.

Bulanin, U., Eriza, M., Masriza, \& Maiyadi, E. (2016). Fekunditas dan diameter telur ikan mingkih Cestraceus plicatilis dalam rangka pelestarian plasma nutfah. Disampaikan pada Seminar Nasional Tahunan XIII Hasil Penelitian Perikanan dan Kelautan, 13 Agustus 2016.

Dhewantara, Y.L. \& Rahmatia, F. (2017). Rekayasa maturasi menggunakan Oodev terhadap synodontis (Synodontis sp.). Jurnal Akuatika Indonesia, 2(1), 35-42.

Effendie, I. (2002). Biologi perikanan. Yogyakarta: Yayasan Pustaka Nusantara.

Fadhillah, R. (2017). Peningkatan Produksi Telur Ikan Nilem (Osteochilus hasselti CV) Melalui Terapi Hormon dan Nutrisi. Jurnal Akuakulturam, 1(1), 37-43.

Farastuti, E.R., Agus, O.S., \& Gustiano, R. (2014). Pendaftaran perkembangan gonad, ovulasi dan pembangkitan pada ikan Torsoro (Pinnacle soro) menggunakan campuran bahan kimia. Limnotek, 21(1), 87-94.

Farida, Gunarsa, S., \& Hasan, H. (2018). Perluasan tepung kunyit dan Oodev dalam pakan untuk mendorong pematangan testis ikan biawan (Holestoma temminkii). Buku Harian Ruaya, 6(2), 7080.

Faridz, A., Alwi, H., \& Sukendi. (2019). Aplikasi Oodev dan tepung kunyit pada pematangan induk ikan semah (Tor douronensis). Jurnal Budidaya Perairan, Fakultas Perikanan dan Kelautan Universitas Riau, Pekanbaru.

Hasan, H., Lestari, T.P., \& Farida. (2018). Penambahan Oodev dan Tepung Kunyit Dalam Pakan Untuk Mempercepat Waktu Maturasi dan Bobot Induk Ikan Biawan (Helostoma teminckii). Jurnal Ruaya, 6(1), 9-20.

Darliansyah, R., Rahim, E.A.S., \& Hasri, I. (2017). Induksi hormon Pregnan Mare Serumgonadotropin (PMSG) dengan dosis yang berbeda terhadap kematangan gonad ikan peres (Osteochilus cappeni). Jurnal Ilmiah Mahasiswa Kelautan dan Perikanan Unsiyah, 2(2), 286-294.

Lijana. (2021). Induksi pemijahan semi alami dengan kombinasi hormon spawnprime dan ovaspec pada ikan peres (Osteochilus kappeni). Skripsi. Universitas Samudra. Langsa.
Marini, M. \& Fahmi, Z. (2015). Potensi Produksi dan Karakteristik Sumber Daya Ikan Danau Laut Tawar. In N.N. Wiadnyana, \& M.M. Kamal. Pengelolaan Sumber Daya Perikanan Danau Laut Tawar Aceh Tengah (hlm. 181-123). Takengon. Amafrad Press.

Makmur, S., Rahardjo, M.F., \& Sukimin, S. (2003). IImu konsepsi ikan gabus (Channa striata) di Daerah Banjir Sungai M usi Sumatera Selatan. Jurnal Iktiologi Indonesia, 3(2), 56-62.

Muchlisin, Z.A. \& Azizah, M.N.S. (2009). Diversity and distribution of freshwater fishes in Aceh waters, northern Sumatera, Indonesia. International Journal of Zoological Research, 5, 62-79.

Purwati, D. (2017). Produksi larva pada induk patin Pangasianodon hypophthalmus betina pasca induksi rematurasi dengan Oodev dan kunyit melalui pakan. Tesis. IPB. Bogor.

Ravindran, P.N., Babu, K.N., \& Sivaraman, K. (2007). Turmeric: The sort curcuma. Clinical and Fragrant Plants-Mechanical Profils. CRC Press. p. 198-199, 278.

Saraswati, T.R. (2013). Optimalisasi kondisi fisiologis puyuh Jepang Coturnix coturnix japonica dengan suplementasi serbuk kunyit Curcuma longa. Disertasi. Institut Pertanian Bogor, $119 \mathrm{hlm}$.

Sari, A. (2016). Pengaruh pemberian Oodev dan tepung kunyit (Curcuma longa) terhadap Performa Reproduksi Induk Betina Lele Sangkuriang (Clarias gariepinus). [Skripsi]. Institit Pertanian Bogor, 53 hlm.

Sari, N., Supratman, O., \& Utami, E. (2019). Aspek reproduksi dan umur ikan ekor kuning (Caesio cuning) yang di daratkan di Pelabuhan Perikanan Nusantara Sungailiat Kabupaten Bangka. Jurnal Enggano, 4(2), 193-207.

Sudrajat, A.O. \& Rasid, H. (2020). Induksi Pematangan Gonad Ikan Lele (Clarias sp.) Menggunakan Oodev dan Kunyit (Curcuma longa) melalui Pakan di Kabupaten Tulang Bawang Barat. Jurnal Pusat Inovasi Masyaraka, 2(1), 90-96.

Tomasoa, A.M., Azhari, D., \& Balansa, W. (2018). Pertumbuhan dan pematangan gonad ikan giru Amphiprion clarkii yang diberi pakan mengandung hormon Oodev. Jurnal Teknologi Perikanan dan Kelautan, 9(2), 163-168.

Unus, F. \& Omar, S.B.A. (2010). Analisis fekunditas dan diameter telur ikan malalugis biru (Decapterus macarellus curvier, 1833) di Perairan Kabupaten Banggai Kepulauan, Provinsi Sulawesi Tengah. Torini, 20(1), 37-43.

Wootton, R.J. (1990). Ecology of teleost fishes. University College of Wales, Aberystwyth. London, $403 \mathrm{pp}$. 